\title{
ADDRESS
}

\section{Sociology, Hypocrisy, and Social Order}

\author{
Professor Layi Erinosho \\ Department of Sociology \\ Olabisi Onabanjo University \\ Ago-Iwoye, Ogun State, Nigeria \\ laierinosho@yahoo.com or erinosho@skannet.com
}

Address of the Interim President at the First General Assembly of the African Sociological Association, Rhodes University, Grahamstown, South Africa, July 2007.

\section{For the Record}

Welcome to the inaugural Congress of the African Sociological Association (AfSA). Sociologists across Africa hardly know, or interact with one another unlike our colleagues in economics and political science that run continent-wide initiatives that bring their members together. There is the West African Economic Association and the Kenya-based African Economic Research Consortium (AERC) Initiative for the training postgraduate economics students across Africa. Furthermore, South Africa currently hosts the African Political Science Association.

The formation of African Sociological Association is driven by the desire to give sociologists in Africa a platform to analyse the continent's social problems and participate in the activities of the International Sociological Association. The formation of AfSA was first mooted at the 1998 World Congress of Sociology in Montreal, Canada. Further discussions followed at the: $30^{\text {th }}$ Anniversary of Codesria, in Dakar; South African Sociological Association meeting in East London; Codesria biannual congress in Kampala, Uganda; and 2006 World Congress of Sociology held in Durban, South Africa.

Three of the regular faces at past consultative meetings on the association are Professors Fred Hendricks and Jimi Adesina, and including the speaker. But the credit for the hard work for this inaugural Congress goes to Professor Jimi Adesina who mobilised a grant from Ford Foundation. Professor Adesina coined the acronym of the Association while Professor Fred Hendricks has been editing our highly rated journalthe African Sociological Review - which is being funded by Codesria, Dakar.

Our immense gratitude to Professor Bayo Oluskohi, the Executive Secretary of Codesria for his tireless support for all noteworthy initiatives that are aimed at promoting scholarship in Africa. AfSA has also enjoyed the unassailable support of Drs Ebrima Sall (Director of Research) and Jean-Bernard Oedraego (Director of Training) at Codesria who are also sociologists.

This Congress would not have materialised without a generous grant from the East Africa Office of Ford Foundation. We wish to thank Ford for the funds and Professor Tade Aina, a distinguished sociologist who is currently heading the East Africa office of the organisation, for embracing our proposal on the formation of AfSA. We wish to 
acknowledge the travel grant from the Lagos Office of Ford Foundation, made possible by Dr Babatunde Ahonsi who is also a well-known sociologist. AfSA is immensely grateful to the National Research Council of South Africa, the ViceChancellor and the authorities of the Rhodes University for their invaluable contribution in cash and kind towards this Congress.

Universities in Africa began to offer sociology degree programmes over sixty years ago. Interest in the discipline has grown as demonstrated by the number of institutions that currently offer degree programmes at the undergraduate and postgraduate levels. Besides, sociology courses have been integrated into various professional programmes like medicine, engineering, architecture, and town planning. Finally, the skills of sociologists are being utilised in government, the private sector, and academia in Africa today.

Pioneer African sociologists succeeded in carving a niche in world scholarship. One of them, our esteemed Professor Akinsola Akiwowo is being honoured at this inaugural Congress for his efforts to indigenise sociological concepts and paradigms. His efforts paid off when the ISA organised a panel on indigenisation and universalism at the 1982 World Congress of Sociology in Mexico City. The International Sociology (the official organ of ISA) also published a series of exchanges on his ideas in its 1986 and 1987 issues. ${ }^{1}$ I salute Professor Akiwowo, my former teacher at Ibadan, and congratulate him most warmly and sincerely for honouring our invitation to accept our award at this historic Congress. Professor Akiwowo was for eight years the only African on the Executive Committee of the ISA. I recall his efforts to bring young African sociologists into the fold of ISA.

Furthermore, it is a privilege and an honour to welcome to this meeting and also congratulate our second awardee, Professor Bernard Magubane, an outstanding scholar and a leading light for generations of African sociologists.

Finally, this inaugural Congress offers us a golden opportunity to celebrate the known and unknown sociologists/anthropologists. I am talking of Amilcar Cabral and Frantz Fanon whose contributions to the study of colonialism and race remain unmatched. The third is our own indomitable Archie Mafeje who passed away recently. Professor Mafeje surmounted all racial barriers through remarkable intellect to establish a niche in world scholarship. AfSA is using this occasion to launch a memorial lecture which will be delivered by another distinguished scholar, Professor Kwesi Prah, in his honour.

Now to my inaugural address.

\section{Introduction}

The founders of western sociology, namely Auguste Comte and Herbert Spencer, proclaimed a secularist proselytising mission because of their emphasis on the application of the scientific method in the production of knowledge that would engender peaceful-coexistence in all human societies. ${ }^{2}$ However, peaceful coexistence, social stability and order continue to elude humankind despite more than a hundred and fifty years of the contributions of sociologists to knowledge. One could therefore surmise that the persistence of conflicts and wars that are religiously, racially, economically, and tribally motivated in all human societies underscores the mistaken idealism and expectations of the founders of western sociology. 
This cynical appraisal of the impact of the contributions of sociologists worldwide towards the study of, as well as the quest for social order inevitably leads to a consideration of a neglected overarching factor in the understanding of the persistence of social conflicts and wars in human societies. And it is vital for African sociologists whose continent is most affected by racially, ethnically, economically, and religiously motivated conflicts and wars ${ }^{3}$ to focus on this factor if others are unwilling to do so.

The aim of this inaugural address is to draw our attention to the role that hypocrisy plays in human affairs. The goal of the discourse would be wellnigh achieved if African sociologists spearhead discourse on hypocrisy in the context of social interactions within and between nations. Hypocrisy appears to be the key to the understanding of the dysfunctions in globalisation, inter- and intra group as well as communal relations. Hypocrisy seems to provide the clue to an unsettled world that is beleaguered by terror.

\section{Conceptual Overview of Hypocrisy}

Hypocrisy simply means 'behaviour which pretends to have a moral standard or an opinion that does not reflect what is actual or the true viewpoint of an individual'. ${ }^{4}$ Another dictionary indicates that hypocrisy is about insincerity by virtue of pretending to have qualities or beliefs that one does not really have'. ${ }^{5}$ Jesus Christ was peeved with hypocrites when he remarked:

Woe to you, teachers of the law and Pharisee, you hypocrites. You clean the outside of the cup and dish, but inside they are full of greed and self-indulgence. Blind Pharisee, First clean the inside of the cup and dish, and then the outside also will be clean. ${ }^{6}$

Similarly, Prophet Mohammad (SAW) noted that:

Hypocrites are known for three shameful acts: when they talk they lie; when they make promise they break it and when they are trusted they betray the trust. ${ }^{7}$

The Holy Qur'an therefore vilifies hypocrites in unmistakable terms:

The Hypocrites - they seek to deceive Allah but is Allah Who deceive them. When they stand up to prayer, they stand without earnestness, to be seen of men but little do they hold Allah in remembrance. ${ }^{8}$

Furthermore,

The Hypocrites will be in the lowest depths of the Fire: no helper wilt thou find for them. ${ }^{9}$

The study of hypocrisy never attracted serious attention until Naom Chomsky began to explore it in the context of world affairs. ${ }^{10}$ The outburst of President Hugo Chavez of Venezuela at the 2006 UN General Assembly where he displayed one of Chomsky's books also helped to draw attention to hypocrisy as a heuristic concept in social analysis and/or in the study of relations between nation-states. ${ }^{11}$

One is compelled to focus on hypocrisy in order to understand social conflict, instability, and wars because the interrogation of overarching factors like social class, poverty, social identities, race, ethnicity etc., by sociologists has so far failed to provide credible answers to the central problematic in sociology, namely, social order. The vision of the founders of western sociology which is to analyse and generate knowledge for the promotion of peaceful co-existence has remained an illusion. Peaceful co-existence and social order will remain elusive so long as there is less 
sincerity and more of hypocrisy within and between nation-states. Following are anecdotal data to support this thesis. This address is expected to push African sociologists to explore the role of hypocrisy in the study of various dimensions of social life, health, inter-group relations, conflict, crime, law, gender, sexuality, labour relations etc.

\section{The West and Rest of the World}

The West has presumably been in the forefront of democracy, good governance, world development, and peace. The United States proclaimed its independence on the platter of no taxes without representation. It entered the first and second world wars in order to protect the sanctity of democracy and human rights. The West under the hegemonic influence of the US fought the former Soviet Union because it regarded communism as an affront to the flowering of the human spirit. Furthermore, the West has been the largest single contributor to peace-keeping in the world. Thus, it is to the eternal credit of the West that democracy which was hitherto regarded as an anathema in many contexts of human existence is being grudgingly embraced even by nation-states that treated it with contempt.

But has the West under the hegemonic influence of the US lived up to these laudable ideals? This has not necessarily been the case if a dispassionate analysis of the role of the West in world affairs is undertaken. The intractable Middle East crisis in which the Palestinians have been waging a relentless war of independence since 1948 is attributable to the inertia on the part of the West to act as the honest broker. The closeness of the US in particular and the West in general to Israel (with the exception of France in certain instances) is stalling the peace process. Dispassionate observers are inclined to argue that the behaviour of the West is inconsistent with its values of democracy and self-determination. It is undeniable that the resolution of the IsraelPalestine crisis would have saved the world from all forms of brutal and catastrophic terror attacks.

The invasion of Iraq by the US and Britain without UN authorization under the pretext that the late Saddam Hussein harboured weapons of mass destruction which were never found is yet another instance of Western hypocrisy. Furthermore, the allegation by President Chavez of Venezuela that the US through the CIA attempted to overthrow his democratically elected regime; the assassination of President Salvador Allende of Argentina including the overthrow of his democratically elected Government by the CIA, as well as the inertia on the part of the US to intervene and enthrone democracy when Liberia badly needed its assistance point to the fact that national interest rather than unfettered commitment to democracy and good governance is central to their mission in, and vision of the world.

The Republic of Iran was a close ally of the US prior to the Islamic Revolution of Ayatollah Khomeini. The US was in fact determined to transform the Shah of Iran into the 'police man' of the sub-region and it armed Iran under the Shah with a sophisticated arsenal. Ironically, the Islamic Republic of Iran is now described as an axis of evil by President George W. Bush of the US.

The unintended consequences of US hypocrisy in its relationship towards Iraq visà-vis Iran are now glaring. The US is at loggerheads with the Shiite dominated Iran over the nuclear weapons/other issues while it is at the same time the main backer of 
the current Shiite dominated regime in Iraq. The overthrow of Saddam has expanded the clout of the Shiite dominated Iran in the Middle East to the chagrin of Saudi Arabia (a close ally of the US) that leads the Sunni worldwide. Ironically, the overthrow of Saddam has altered the balance of power in favour of Iran, the arch enemy of the US that also backs Sunni-dominated Saudi Arabia and Lebanon.

Finally, the US worked hand-in-hand with Osama Bin Ladin and the Mujahadeen to defeat the former Soviet Union in order to contain the spread of communism in Afghanistan. ${ }^{12}$ Ironically, Osama Bin Ladin who received all his training in terrorism under the tutelage of the US/CIA is now regarded by the US as its number one enemy as a result of $9 / 11$ and other alleged terror attacks.

But hypocrisy as a tool in social and international relations is not the preserve of the US alone but also underpins the behaviour of its European allies, notably, the United Kingdom, France, and Germany. The United Kingdom under Tony Blair collaborated in the invasion of Iraq. Secondly, Britain's hypocrisy is glaring in the legal manoeuvrings over the extradition of the late General Augusto Pinochet to Spain over criminal charges on the disappearance/death of not less than 3000 during his regime. Baroness Margaret Thatcher, Britain's former Prime Minister was quick to remind Tony Blair that the United Kingdom owed a lot to the General for the support that he gave to their country during the Falklands War and it was necessary for the British establishment to show appreciation towards the General during his travails. The General was somehow allowed to return to Argentina instead of being extradited to Spain to answer the charges.

Thirdly, there seems to be a gap between commitment to transparency and accountability on the one hand and national interest on the other as amply shown by the way in which the British Government stalled the investigation into a deal on the procurement of sophisticated fighter aircraft by Saudi Arabia from the Untied Kingdom. What follows is the reaction of a senior Minister when the Liberal Democrats demanded an investigation into the deal:

'I have, as in normal practice in such as sensitive case, obtained the views of the Prime Minister and Foreign and Defence Secretaries as to the public interest considerations raised by this investigation', the Attorney General told the House of Lords yesterday. 'They have expressed the clear view that continuation of the investigation would cause serious damage to United Kingdom/Saudi security, intelligence and diplomatic cooperation which is likely to have seriously negative consequences for the United Kingdom's public interest in terms of both national security and our highest priority foreign policy objectives in the Middle East'.

The Conservatives accepted the statement, and said the affair should end there, but the Liberal Democrats accused the Government of giving into Saudi pressure. ${ }^{13}$

No criminal charges have been laid against those that are involved in the deal/scandal.

Fourthly and just lately, all the soldiers of British Commonwealth origin who are currently serving in the British Army formed a Union to fight all sorts of discriminatory practices that are targeted at them. A Belize-born named Marlon Clancy who is spearheading the Union claimed that 'other soldiers dressed as members of the $\mathrm{Ku}$ Klux Klan' attacked him and were saying: 
they were going to take the 'nigger' to burn. That black people never used to have rights, they shouldn't have rights now.

Mr Clancy, still a serving soldier, said his complaints were not acted upon - 'Nothing was done. Because I made the complaint I was further victimised' ${ }^{14}$

One could therefore surmise from the foregoing examples that the United Kingdom is after all inclined to sacrifice human rights in favour of its national interest.

Although the French did not endorse the invasion of Iraq by the US and Britain, a stance that angered its long time allies and one that caused the now discredited and jailed Republican congressman Bob Ney to rename French fries as freedom fries, ${ }^{15}$ they are by no means devoid of hypocrisy. While the French revolution was fought on the platter of Liberté, Egalité, Fraternité, this sentiment is not always manifested in their behaviour.

The French were very hostile to Guinea when the late Sekou Touré was the only nationalist leader in colonial French Africa to demand independence for his country and Guinea was singled out for serious punishment. Moreover, the French hurried out of Vietnam after they were defeated and they were also forced to grant independence to Algeria after thousands of Algerians had lost their lives. Thirdly, they have a discriminatory immigration policy despite their pride regarding the rainbow team that won the world cup five years ago under the leadership of Zinedine Zidane, the son of an Algerian immigrant. Finally, no observer would gloss over the conditions under which African immigrants live in France today. The 2006 riots by African immigrants most especially in Paris bear testimony to the hypocrisy of the French over access to basic social and economic rights for people of colour.

So much about politics: let us turn attention to the hypocrisy of the West in the context of the world economic system. The attempt to regulate world trade through the WTO has turned out to be a ruse after all. Low income countries that envisaged that the WTO would make it possible to maximize gains on their agricultural products in the context of a regulated world market are now disenchanted due to the absence of a level playing field for all nation-states. While the high-income countries surreptitiously continue to subsidise their goods and are able to protect their industries, the low income ones are being forced/manipulated to remove subsidies from theirs. Here are some reactions from the South towards the implementation of WTO.

First, Kweku Fukuo from Ghana remarked: ${ }^{16}$

I still do not know exactly what Africa expects of the WTO. It seems to me we only attend because everybody else agrees we are poor and to hear what the rest of the world can do for us. What a pity. The level of apathy is just too dangerous. Well, cocoa may not be affected now, first it was sugar, then each other products that we export and then we will find out we are not needed in these meetings.

Victor Owo from Nigeria intoned: ${ }^{17}$

As a Nigerian and an African, I don't expect much from the WTO, what I know for sure that they will bring up policies that will make Africans poorer. Ghana sends cocoa to the developed world, and then it comes back as chocolate, more expensive than the cocoa itself. This only makes the rich countries richer.

What about Mitsuru from Japan who argued that: 
African governments should put pressure on the international community to make realistic and reasonable profit from the international trade. While I pay $\$ 3$ for a cup of coffee in Japan, Kenyan farmers get peanuts instead of what they really deserve. It is not a trade in modern times. What a shame.

And also John Alege of the United Kingdom who claimed that: ${ }^{18}$

The WTO is hinged on capitalist domination of the global economy. African countries are advised to adopt free market economy, removal of trade restrictions, yet the world's rich countries protect their producers and restrict African exports. It is now time for WTO to, not only consider creating enabling conditions but also remove those that continue to weaken the nation states in Africa.

Other Western European Countries have also not been above board on hypocrisy as amply shown by the protest of a group of Norwegians who were fathered by German soldiers during the Second World War who are now seeking redress over the violation of their human rights. One hundred and fifty Norwegian adult children are seeking compensation through the European Commission of Human rights for alleged harassment/abuse dating back to 60 years! $!^{19}$

\section{The West and Africa}

Africa is poverty stricken as amply shown by the UNDP annual statistics that indicate that most of the poorest countries in the world are in Africa with nearly two-thirds of the population in the continent living on a US dollar a day. ${ }^{20}$ Sub-Saharan Africa is also ravaged by parasitic and infectious diseases, the most virulent among them is HIV/AIDS. The prevalence rates of HIV/AIDS which currently lacks cure range from about two percent in countries like Senegal to about 20 percent in Southern African countries (South Africa, Botswana, Lesotho, Swaziland), making sub-Saharan Africa the carrier of the heaviest burden of the disease worldwide. ${ }^{21}$

The institutions of many African countries are in a state of disrepair. Affordable health care is still elusive to large segments in the population while universal and/or quality education is also not yet accessible to all. Child labour is widespread and millions of the able-bodied are underemployed or unemployed.

Girl-children and women who constitute a formidable subgroup in the population in Africa are still brutalised in various ways because they are the targets of wide ranging harmful cultural practices that are embedded in the social structure of the various communities in the continent. ${ }^{22}$ Infant and maternal mortality rates are still at an all time high. ${ }^{23}$ African women are more likely to die during child birth than their counterparts elsewhere in the world while substantial proportions of their children die before the age of five. Life is cheap in Africa because of these factors.

One of the reasons for the dismal state of Africans and Africa can be attributed to corruption among its top public functionaries. Most African countries are among the most corrupt in the world. ${ }^{24}$ African leaders consistently demonstrate the neurotic need for power and money. Elections are hardly free and fair and those who assume the mantle of leadership through rigged elections enrich themselves within the shortest possible time. Besides, they are determined to hang on to power in clear violation of their country's Constitutions. 
The West is always inclined to bemoan corruption among African leaders while the World Bank/IMF is quick to underscore its implications for good governance and rapid economic development in Africa. They attempt to put pressure on African countries to behave through Transparency International Corruption Perceptions Index which is the framework for ranking countries on corruption worldwide. ${ }^{25}$

Paradoxically, African leaders remit the funds that they siphon from their national treasuries to banks in the high income countries. The late President Mobutu Sese Seko of Zaire, now Congo, Kinshasa, who enjoyed the support of the US/CIA during his thirty-two year reign of terror stole not less than US\$5 billion which he kept in Swiss Banks. And it has been suggested that all the funds that were stolen by Mobutu equal the foreign debt of his country. The late General Sani Abacha, the former Nigerian dictator, transferred not less than US $\$ 1.5$ billions from Nigeria to banks in Europe and other parts of the world. The former Governors of Bayelsa and Plateau states in Nigeria were caught in the United Kingdom carrying huge amounts of US dollars and pounds sterling. Finally, it was suggested at one time that a handful of Nigerian leaders could easily pay off the debt of about US $\$ 33$ billion which the country owed its creditors before substantial proportions were written off by Western creditors.

Another report claims that 'at least US\$1 billion of illegal gains made by former and serving politicians and civil servants in Kenya, were uncovered' while the Goldenberg scam involved between US $\$ 3$ and 4 billions of revenue that are stashed away in foreign banks. ${ }^{26}$ The banks in Luxemburg, Britain and most especially in Switzerland where authorities enforce secrecy in banking transactions are 'reputable' for receiving stolen and misappropriated funds from Africa and other third world countries.

The standpoint of the West on corruption smacks of hypocrisy because the West is by and large the sole recipient/beneficiary of stolen public funds from third world leaders. While assuming a moral high ground through 'sermons' on the importance of good governance in Africa, the West often turns a blind eye to its banking institutions that receive and live off stolen funds. It is a trite observation in common law that a thief/corrupt individual/organisation and any person/organisation that knowingly receives stolen goods is criminally liable.

Attempts by third world and African countries to retrieve stolen funds from its banks are hampered in various ways. The erstwhile Nigerian administration needed all the wits to retrieve just a part of the stolen funds which Sani Abacha deposited in western banking institutions. Congo Kinshasa has so far not recovered from Western banking institutions the billions of dollars that Mobutu Sese Seko stole during his long reign. The Philippines has so far not retrieved most of the funds that Ferdinand Marcos stole from the country.

What would it be like if all corrupt African leaders had no safe haven in the West for stolen and misappropriated public funds? What would it be like if western banks and their governments voluntarily disclose and return stolen funds without legal and bureaucratic hurdles? What would it be if there is an Index of transparency for the recipients of stolen funds just like the one that currently ranks countries on the scale of corruption worldwide? What would it be like if all the stolen funds are kept in banks within Africa? Not only will the West be upholding its proclaimed commitment to democracy, transparency, and good governance, it will also be making positive 
contribution towards freeing Africans from the exploitation by their leaders. The West has not helped by its hypocritical stance on stolen funds. Rather, the West seems to be colluding with African leaders to exploit the peoples of Africa.

\section{Hypocrisy in Africa}

Hypocrisy is a universal phenomenon because it also transcends social and inter-state relations in Africa. A number of examples will drive this point home starting with the Organisation of African Unity (OAU), now African Union(AU).

Africans are still as far apart as possible despite nearly five decades of the existence of OAU/AU. The mass deportation of Nigerians from Ghana by the late Dr K. A. Busia and retaliation by Shehu Shagari of Nigeria demonstrate the gap between the proclamation of African unity and brotherliness/sisterliness among Africans. What about the forcible eviction of Nigerians from Equatorial Guinea or the incarceration and brutal treatment of Nigerians who are attempting to cross to Europe by the Libyan and Moroccan Authorities? How else could one explain the fact that it is more tasking for Africans to obtain visas to African countries than Euro-American countries? The African Union is meaningless if there is no free movement for Africans within their continent. Freedom of movement around Africa is therefore the minimum condition for economic, political, and social integration.

There are other examples of hypocrisy at country level in Africa and we would discuss a handful staring with Nigeria. The erstwhile administration in Nigeria proclaimed the fight against corruption as one of its cardinal goals. The Obasanjo Administration enacted a law that established the Economic and Financial Crime Commission (EFCC) to demonstrate its commitment to this goal. The agency has been hitting the headlines and a week hardly goes by without reports of Governors or legislators or Chairmen of Local Government Authorities including top civil servants that are under investigation or arrested for corruption or misappropriation of public funds. Yet, the credibility of EFCC is being questioned due to its double standards. Critics argue that the erstwhile Head of State used EFCC to target his political enemies. They also note that the Commission has not come clean on the weighty allegations that are levelled against the former President and his friends over use/misuse of public funds in the President's bid for a third term in office. Nor has the agency convinced the public on the veracity of allegations concerning the acquisition of shares by top government officials in privatised government firms. There is therefore a divergence between what the administration professed and its response to corruption. One commentator observed:

Sir from the undisputable description of a hypocrite (i.e. from Prophet Mohammad's (SWA) standpoint), will it out of place to conclude that today's leadership in Nigeria is hypocritical? Nigerians have been told endless lies. They have been promised in vain. Their trust in the leadership has been betrayed. Thus, the only thing that seemed to remain in their possession before now has turned forlorn. And that is hope. Yet the same leadership continues to preach patriotism to the hopeless populace as if patriotism can be achieved in a vacuum. At least people can still remember your promise. Shortly after you were sworn into office as President in 1999, that there would be no First Lady for you and that you would not appoint more than 21 Ministers. Were those promises fulfilled? And shortly after that, you also promised Nigerians that your Government would make electricity stable within six months. In the end, more than one trillion has been spent on 
electricity before we were told that the monster NEPA (now PHCN) had become insuperable problem. With such colossal sum sir, sincere government somewhere else would have turned a country like Nigeria into an 'Eldorado'.

Further to the East, the present Kenya Administration was elected because the Moi Regime was believed to be corrupt. However, the Kibaki Administration is also enmeshed in corruption. The Head of Kenya anti-corruption agency ${ }^{28}$ escaped to London in 2006 because he feared for his life. According to him, he had become the target because the government was unwilling to give him the necessary support to deal with corrupt officials. ${ }^{29}$ Not too long ago, the Government of Kenya hurriedly deported two Armenian Brothers with strong connections with the presidency. The public felt this step was taken in order to forestall a high-powered enquiry whose outcomes might have linked top government functionaries and/or their next of kin to corrupt deals that are detrimental to the people and Government of Kenya.

Then there is the crisis in Ivory Coast which has split the country into two simply because the authorities changed the Constitution to ban a Northern Muslim opposition leader from contesting for the presidency on the ground that he is a foreigner despite the fact that he previously served meritoriously as the country's Prime Minister!

What about the Government of South Africa that has been criticised by civil society organisations and the international community over its stance on HIV/AIDS despite the fact that the prevalence rate in the country is among the highest in the world? ${ }^{30}$ Besides, former Vice-President Jacob Zuma complicated matters further when he claimed that he successfully prevented HIV/AIDS infection by taking a quick shower after sexual intercourse with an infected lady friend!

South Africa has approved same sex marriage despite the fact that opinion poll indicates that most South Africans are not in favour of same sex marriage. The decision to approve same sex marriage seems to downplay the feeling of the majority in the population. This is a situation in which there is conflict between popular opinion and judicial directives/constitutional provisions on human rights and what remains to be settled is which should take precedence over the other. All of these send mixed signals and lack of candour in public policy and there is no better way of summing up the situation in South Africa today than in the words of our redoubtable Professor Ali Mazrui who observed as follows:

With the collapse of political apartheid in South Africa in 1994, the danger of white domination of South Africa receded. But the risk of South Africa being dominated by white values increased. When South Africa devised the most liberal constitution in the world, it was on its way towards embracing the West through its own civilisation. South Africa has abolished the death penalty long before the US has done. And South African gays and lesbians have received more civil rights than gays have done in much of the rest of the world. The dictatorship of the white man has ended in South Africa, but has the dictatorship of white values triumphed? $?^{31}$

Arab Africans are inclined to look down on black Africans, describing them in subhuman terms. This attitude led to years of civil war between the Arab North and the Black South in Sudan and it also explains the on-going crisis in Darfur in which thousands of black Africans who are mostly Muslims like their Arab brothers/sisters have been (and are still being) killed by the Janjaweed with the support of the Arab 
Islamic Khartoum regime. Ironically, the black African countries that always support the Palestinians in their struggle as well as the Arab League over the Israel-Palestine conflict have not made a big issue over the genocide in Darfur.

\section{Hypocrisy and Sociology}

What do the foregoing anecdotal analyses of behaviour patterns in the West and Africa mean? They only indicate that there is a window of opportunity for sociologists to interrogate hypocrisy in their study of social interaction and international relations. The study of hypocrisy in diverse contexts of social interaction holds the key to the understanding of persistent social conflicts and wars. Such efforts are likely to produce the knowledge for tackling social conflicts and wars within and among nation-states.

Talking about the study of hypocrisy inevitably brings into focus the seminal contributions of the Chicago School of sociology to the analyses of nuances and social processes in human behaviour and groups. Therefore, we cannot but revisit the works of Erving Goffman which include The presentation of self in every life, Asylums, Stigma, etc.

There is room for macro and micro-sociological studies on the contribution of hypocrisy to social disorder worldwide. We need studies that ascertain the trajectory of stolen and misappropriated public funds by African leaders, focusing on their magnitude, recipients, and impact on poverty in the continent. We need comparative studies on stolen funds in western banking institutions vis-à-vis the flow of the much desired foreign direct investment (FDI) into African countries. We need to expose the hypocrisy of the different actors that exacerbate corruption, bad governance, poverty, social disorder etc., in Africa.

Furthermore, we need to focus on voting patterns in the general assembly and the security council of the United Nations and their implications for peaceful co-existence in the world. It is desirable for African sociologists to take a critical look at what, why and how African leaders are managing the affairs of their countries and the impact of their actions on poverty alleviation and economic development. We need studies whose outcomes will prick the conscience of the West and our leaders; studies that will bring the much desired change in our continent.

\section{Concluding Remarks}

In concluding, the study of hypocrisy is the key to the understanding of terrorism which now transcends all the sub-regions of the world. Peace and social order will continue to elude humankind unless we interrogate hypocrisy in the study of social relations, economy, and politics. To sum up, the vision/mission of the founding fathers of western sociology will remain a mirage unless and until African sociologists spearhead the study of the role of hypocrisy in social conflicts and wars within and among nation states.

\section{Notes}

1. See A. Akiwowo, 'Contribution of Sociology of Knowledge from An African Oral Poetry', International Sociology, Vol. 1, No. 4, December 1986, 343-358; A. Akiwowo, 'Universalism and Indigenization in Sociological Theory: Introduction', International Sociology, Vol. 3, No. 2, 1988, 155-160; A. Akiwowo, 'Indigenous Sociologies-Extending 
the Scope of the Argument', International Sociology, Vol. 12, No. 2, 1999, 115-138; O.B. Lawuyi, and O. Taiwo, 'Towards an African Sociological Tradition', International Sociology, Vol. 5, No. 1, 1990, 57-74; M.A. Makinde, 'Asuwada Principle: An Analysis of Akiwowo's Contribution to the Sociology of Knowledge from an African Perspective', International Sociology, Vol. 3, No. 1, 1988, 61-76.

2. Auguste Comte, The Positive Philosophy, freely trans. and condensed by Harriet Martineau, 3 vols, Calvin Blanchard, New York, 1855; T. Timascheff, Sociological Theory, Random House, New York, 1967.

3. Africa has been the theatre of conflicts and wars for several decades. Some of them are: the civil war in Nigeria; war of liberation in Southern Africa; post independent war in the former Portuguese territories; the civil war in Congo and much more recently that that attracted the involvement of other neighbourin countries like Rwanda, Uganda and Zimbabwe; the civil wars in Sierra Leone and Liberia; Sudanese war in the south and the ongoing one in Darfur, Ethiopia-Eritrea war, Somali war, Western Sahara against Morocco; the civil war in Algeria in the run off to independence and following the annulment of the election that the Islamic Party was poised to win, etc.

4. See Oxford Advanced Learner's Dictionary, 2000.

5. Wordreference.com, English Dictionary, 2006.

6. Holy Bible

7. See Abbas, The Nation (Nigeria), 2007

8. See Verse 142, Women IV, Part 5 of the Roman Transliteration of the Holy Qur'an, by A.Y. Ali, Published by Alhaji Sanni Danjinjiri, Kano, 1934, p.104.

9. See Verse 145 of Part IV, Women IV of the Roman Transliteration of the Holy Qur' an by A.Y. Ali Published by Sanni Danjinjiri, Kano, 1934, p.104.

10. See Noam Chomsky, Case Studies in Hypocrisy - Human Rights Policy, AK Press, 1999.

11. N. Chomsky, Hegemony or Survival America's Quest for Global Dominance, Henry Holt and Company, New York, 2001.

12 M.A. Gress, et al., ed., The Soviet-Afghan War: How a Superpower Fought and Lost, University of Kansas, 2002.

13. BBC politics.co.uk Friday December 15, 2006.

14. BBC New Wednesday 7 March 2007, http://news.bbc.co.uk/2/hi/uk_news/6425529.stm.

15. The Nation (Nigeria), January 21, 2007.

16. 'What can Africa expect from WTO', BBC News, http://news.bbc.co.uk/1/hi/world/africa/4511628.stm, December 16, 2005.

17. ibid.

18. ibid.

19. 'Commonwealth Soldiers Form Union', See BBC News Wednesday 7 March 2007, http://news.bbc.co.uk/2/hi/uk_news/6425529.

20. UNDP 2006 Human Development Report, UNDP, New York.

21. UNDP2006 Human Development Report, UNDP, New York.

22. See reports of Inter-African Committee for the Prevention of Harmful Practices Affecting Women and Children in Africa.

23. UNDP 2006 Human Development Report, UNDP, New York and WHO 2006 Annual Report, WHO, Geneva.

24. The countries that are poorly rated are: Kenya, Nigeria, Sierra Leone, Côte d'Ivoire, Equatorial Guinea, Chad, Sudan and Niger. 
25. The 2006 Transparency International Corruption Perceptions Index, http://www.infoplease.com/ipa/A0781359.html

26. Kenya Economy - Development So Far, Corruption worth US\$1 billion Disclosed in Kenya, http://www.afrol.com/articles/10709, 03 January 07.

27. Femi Abbas, 'The Message: No! Mr. President, No!', The Nation, Friday February 2, 2007.

28. Mr John Githongo was interviewed on the BBC over the scale of corruption in Kenya and why he ran for his dear life.

29. BBC News Africa February 15, 2006.

30. HIV/AIDS in South Africa AVERTing HIV/AIDS updated November 2005 indicated that the prevalence rate among pregnant women was 30.2 percent in 2005.

31. Ali Mazrui, 'Clash of Civilizations', BBC Focus on Africa, Vol. 18, No. 2, April-June, 2007, 36. 